\title{
Necessity and Perspective of the Evolution of Electronic Banking Services
}

\author{
Ioana LAZARESCU ${ }^{\star}$, Viorica IOAN $^{\star \star}$, Costinela FORTEA ${ }^{\star \star \star}$
}

\begin{tabular}{l}
\hline \multicolumn{1}{c}{ A R T I C L E I N F O } \\
\hline Article history: \\
Accepted March 2020 \\
Available online May 2020 \\
\hline JEL Classification \\
G21, M20 \\
Keywords: \\
Banking services, e-banking, \\
Internet banking, Mobile banking
\end{tabular}

1. Introduction

E-banking began to develop in the United States of America, beginning in 1995, the year in which the US Presidential Bank of Maryland launched the first Internet banking services. (Răbonțu C.I., 2009). As of mid-2004, over 17\% of Americans were using electronic banking. By 2003, electronic banking was already very popular in Europe. In Romania, electronic banking services have grown rapidly in recent years and are still developing and expanding.

Before 2010, mobile banking was most often performed by SMS. With the advent of WAP-supported smartphones in 1999, the first European banks started offering customers services on this platform through the mobile banking application. Apple's initial success with Iphone and the rapid growth of Android-based phones (operating system) have led to the increasing use of mobile applications, downloaded to mobile phones, as well as mobile banking.

Banks that operate in Romania and have the right to provide e-banking services, are nominated in accordance with Order no. 553 of June 5, 2019 regarding the regulation of the procedure for approving electronic payment instruments with remote access issued by the Ministry of Communications and Information Society regarding the procedure for approving electronic payment instruments with remote access, such as Internet Banking or Mobile Banking. Therefore, banks have the obligation to implement IT security measures, to continuously monitor and to evaluate annually the operational risks generated by the use of information systems through which the electronic payment instrument with remote access, in compliance with the laws and internal regulations is provided.

The bank has begun to develop its activities with the help of electronic banking services, which are used effectively by customers. "Mobile banking is the latest and most innovative service offered by Banks". (R. Ayswarya, D. Sarala, P. Muralidharan, M. Ilankadhir, 2019).

Keivani (2012) describes electronic services as "an umbrella term for the process by which a customer may perform banking transactions electronically without visiting a brick-and-mortar institution."

Mobile banking, as opposed the internet banking, uses software, usually called an application. It depends on the availability of an internet or a data connection to the mobile device. The transactions through the services offered by the mobile banking application depend on the characteristics offered by each banking institution and usually include obtaining account balances and lists of the most recent transactions, electronic invoice payments, transfers of funds between the accounts of a bank. client or another.

\section{Internet banking at EU level}

Internet banking is used for banking transactions via the Internet. It allows bank customers to run operations outside of business hours, wherever they have Internet access. In some cases, a normal web 
browser with any kind of Internet connection is used for these operations, but in other cases it is necessary to use devices provided by the bank.

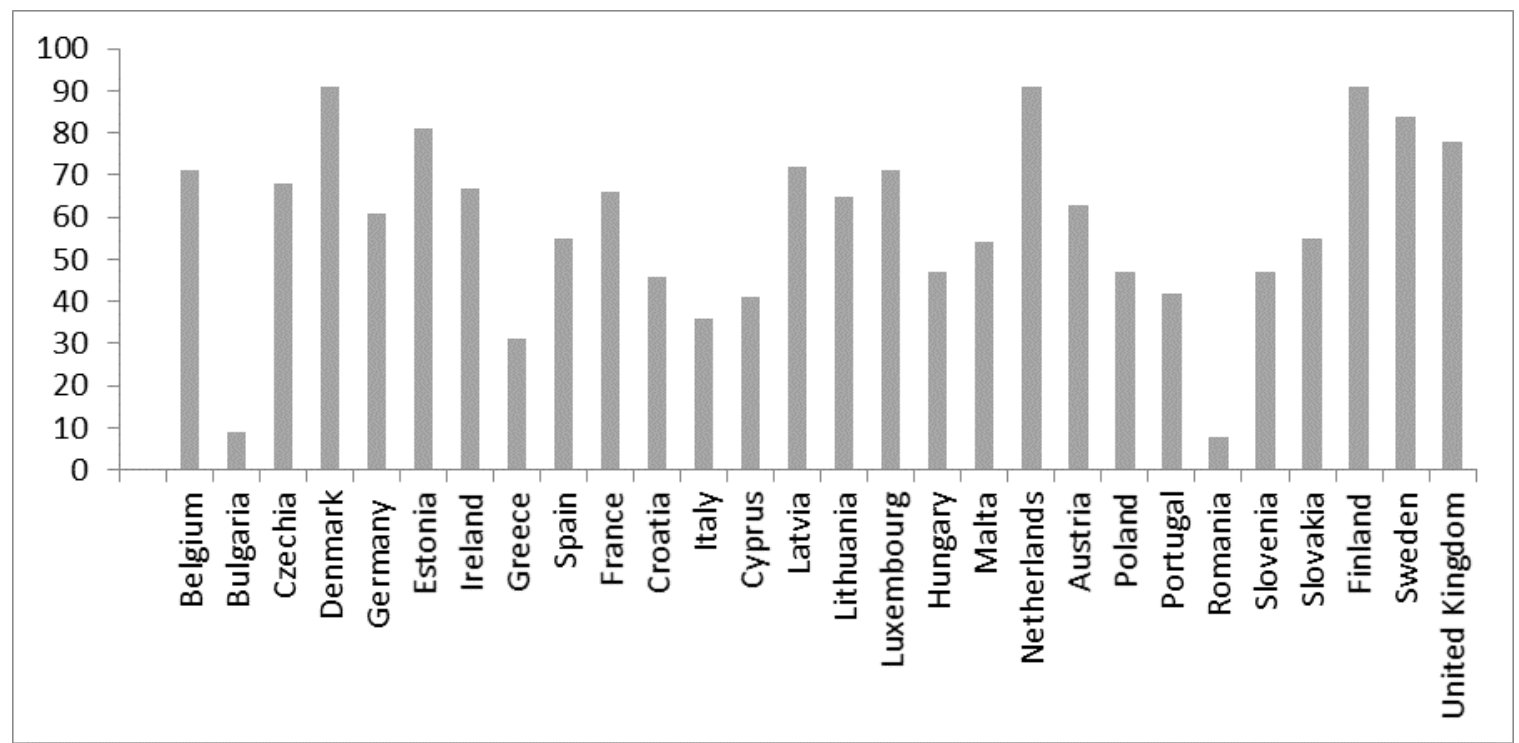

Figure 1. People using internet banking at EU level in 2019 (\%)

Source: Developed by the authors, information available on Eurostat

According to Eurostat data shown in Figure 1 among the Member States of the European Union, internet banking services are most used in Denmark, the Netherlands and Finland (91\%) followed by Sweden (84\%). The smallest shares were registered in Romania (8\%) and Bulgaria (9\%).

\section{Electronic banking services in Romania}

Internet banking - can usually be accessed through a web browser (Internet Explorer, Firefox, Opera, Chrome, Safari) at a secure website address, such as https (hypertext transfer protocol secure), a site made available and maintained by to the bank. On these secure sites, each client subscribed to internet banking has a valid account, like the email. Thus, for the connection and use of the service, the user enters an ID and a code generated by a portable electronic device made available (free or at a cost) by the bank. These devices are called Generic Secure Digital Token but have different names depending on the bank.

According to Eurostat data presented in Figure 2, we observe an increase in the evolution of electronic banking in Romania, during the last 10 years.

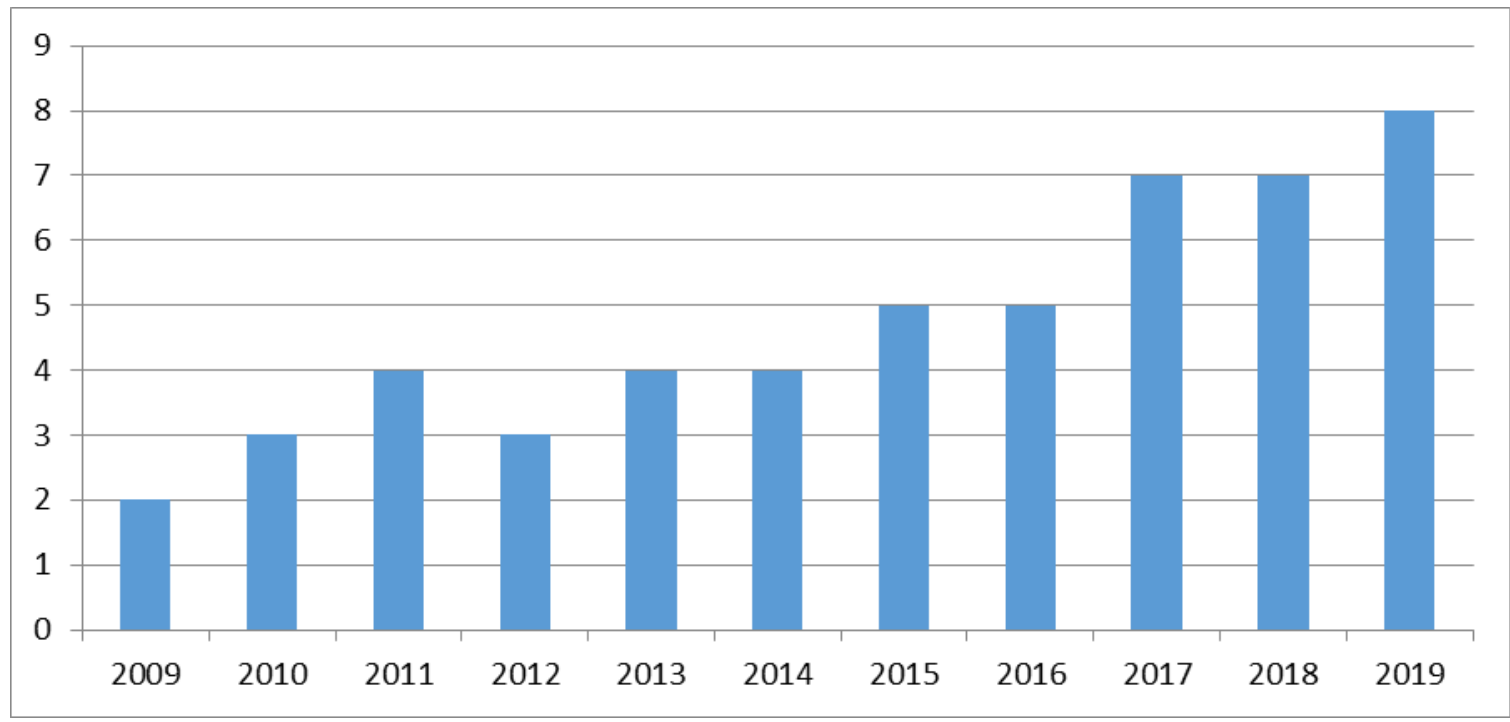

Figure 2. People using internet banking in Romania (\%)

Source: Developed by the authors, information available on Eurostat

In order to obtain a clearer picture of the development of electronic banking in Romania, a study was conducted in which the banks in Romania identifying these services and the types of services made available to customers were identified. The results of the study are presented in Table 1. 
Table 1. e-banking services offered by banks in Romania in 2019

\begin{tabular}{|c|c|c|c|}
\hline Nr.crt. & Name of the banking institution & Internet Banking & Mobile Banking \\
\hline 1 & Alpha Bank România & Alpha Online Banking & Alpha Online Banking \\
\hline 2 & Banca Română de Credite şi Investiţii & - & - \\
\hline 3 & Banca Comercială FEROVIARA & BCF Online & BCF mobile banking \\
\hline 4 & Banca Comercială Intesa Sanpaolo & I-B@nk & Intensa Sanpaolo Mobile \\
\hline 5 & Banca Comercială Română & Click 24 Banking BCR & George \\
\hline 6 & $\begin{array}{l}\text { Banca de Export-Import a României } \\
\text { EXIMBANK }\end{array}$ & e-ximBanking & Eximbank Mobile Banking \\
\hline 7 & Banca Românească & e-bancamea & - \\
\hline 8 & Banca Transilvania & BT24 & BT24 \\
\hline 9 & Bank Leumi România & Leumi Online & Bank Online \\
\hline 10 & BRD - Groupe Société Générale & MYBRD NET & MyBRD Mobile \\
\hline 11 & CEC Bank & CEConline & CEC Bank Mobile Banking \\
\hline 12 & Crédit Agricole Bank România & I-Conect & m-conect \\
\hline 13 & Credit Europe Bank & CreditEuropeNet & CEBLine \\
\hline 14 & Garanti Bank & Garanti BBVA Online & Garanti BBVA \\
\hline 15 & Idea Bank & Idea::iBank & - \\
\hline 16 & Libra Internet Bank & Libra Internet Bank & Libra Mobile Banking \\
\hline 17 & Vista Bank & Vista Internet Banking & Vista Mobile Banking \\
\hline 18 & OTP Bank România & OTPdirekt & OTP SmartBank \\
\hline 19 & Patria Bank & Patria Online & Patria Mobile Banking \\
\hline 20 & First Bank & & \\
\hline 21 & Porsche Bank România & PorcheBank@YOU & Mobile@YOU \\
\hline 22 & ProCredit Bank & ProCredit Direct & MB@nk \\
\hline 23 & Raiffeisen Bank & Raiffeisen Online & Raiffeisen Smart Mobile \\
\hline 24 & UniCredit Bank & Online B@nking & Mobile B@nking \\
\hline 25 & Alior Bank & Telekom Banking & Telekom Banking \\
\hline 26 & BLOM Bank France sucursala România & eBanking & Eblom Mobile \\
\hline 27 & Citibank România & CitiDirect Online Banking & CitiDirect BE \\
\hline 28 & ING Bank & ING Home Bank & ING HomeBank \\
\hline
\end{tabular}

In Romania, most of the financial banking institutions provide the internet banking service in order to complete the current offer, as an extension of their services in the virtual environment. Access can be requested from the first day of contact with the bank, but also later.

The use of Internet Banking has become an increasingly widespread and accepted solution among the public as an alternative to the classical method by presenting it in a banking branch to perform the usual operations.

Security measures related to the online use of accounts are constantly evolving and are an integral part of banks' security policies.

\subsection{Mobile banking}

Mobile banking is a service that offers the possibility to manage bank accounts by simply using the mobile phone connected to the Internet. In all cases, the mobile banking service is adjacent to the internet banking service offered by the respective bank.

Mobile Banking is a payment instrument with remote access, which involves the use of mobile equipment (smartphone, tablet, PDA - Personal Digital Assistant, etc.) and services offered by telecommunications operators.

The main operations provided by the Romanian banks through Mobile Banking are:

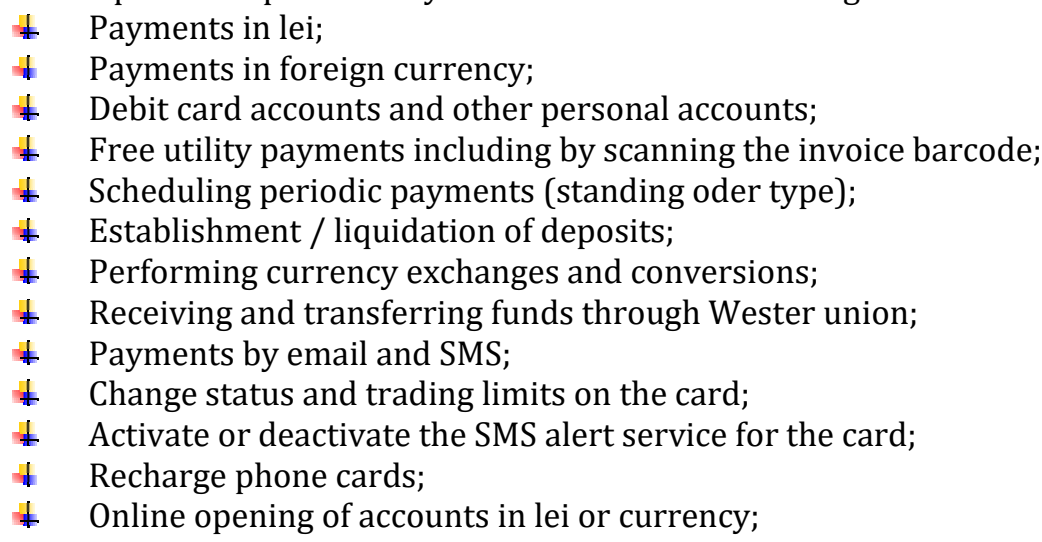


* Re-issuing the password online;

\& Mobile device management;

$\$$ Online reissue of the PIN of the card.

Banking information provided by Romanian banks through Mobile Banking are:

* Checking the account balance;

Account details, including credit card turnover;

* Transaction history;

* View details of deposits and loans;

* Loan simulator;

* View status and card limits;

* Exchange

* Download daily and monthly account statements for a period of 1 year ago;

* The status of the transactions initiated on all electronic channels;

* View transfer status Wester Union;

* View scheduled payment orders.

The Mobile Banking application can be customized, in terms of preferred language, date / time format, default transactions, list of standard beneficiaries, alerts.

Electronic banking services can be obtained through a mobile phone (Mobile Banking), in two ways: by using SMS messages and by accessing the Internet. For the use of SMS messages, a special mobile phone number of the bank is formed, and for access to WAP, an Internet address of the bank site or a server of the mobile operator, which is also connected to the bank, is formed. As a rule, SMS messages receive various information regarding the account balance and the history of the last transactions, and through WAP access pages with the same information are received, to which general bank information can be added, regarding commissions, interest, current exchange rate, network ATMs of the bank and others.

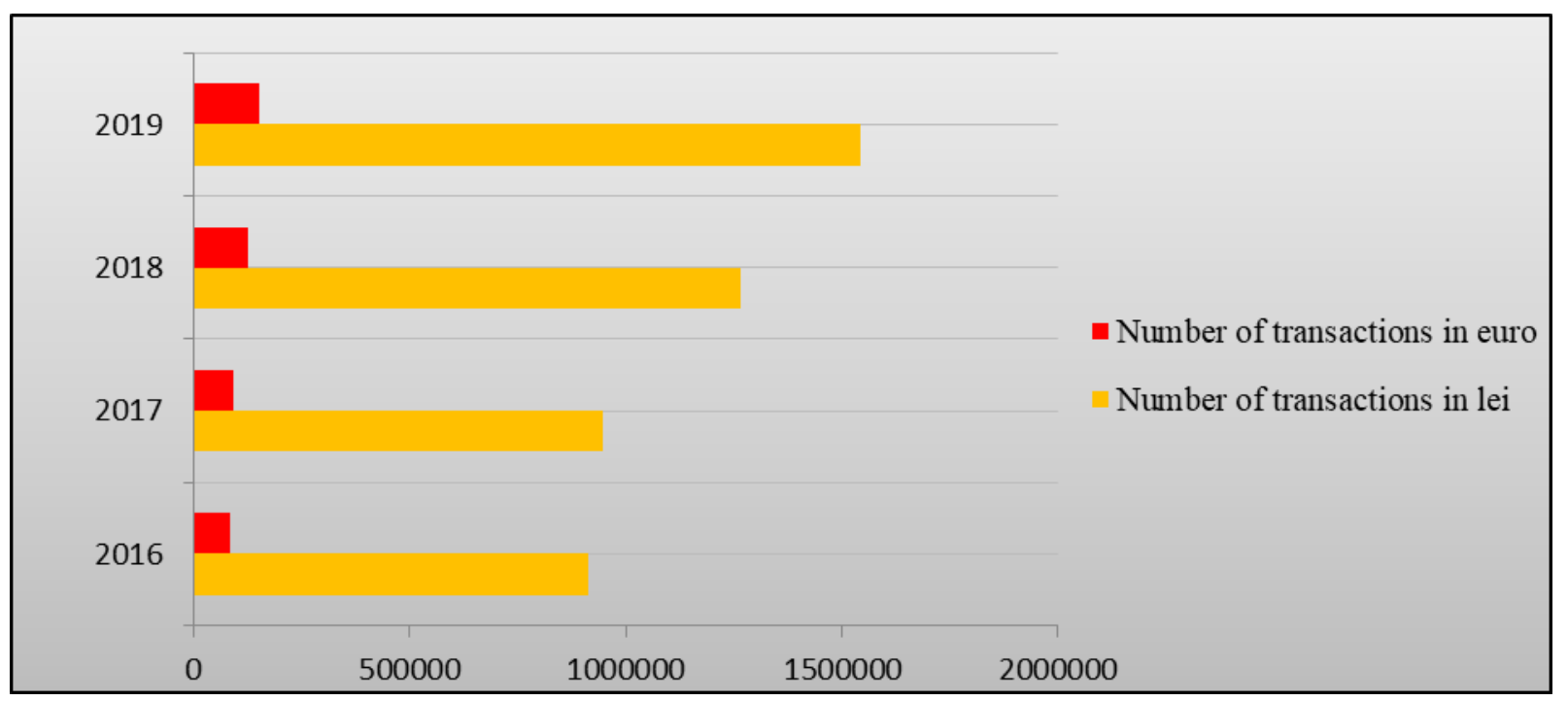

Figure 3. Number of transactions in lei and euro offered by mobile banking in Romania Source: Elaborated by the authors, data from BNR reports

Regarding the number of transactions, between 2016-2019, it is noted that most of them were realized in Lei. Therefore, the number of transactions in lei in 2018 compared to 2017 increased by $33.6 \%$ and in 2019 compared to 2018 they increased by 21.9\%. Both the number of transactions in Lei and in Euro had an increasing evolution from year to year, as well as an overall evolution of the number of transactions. 


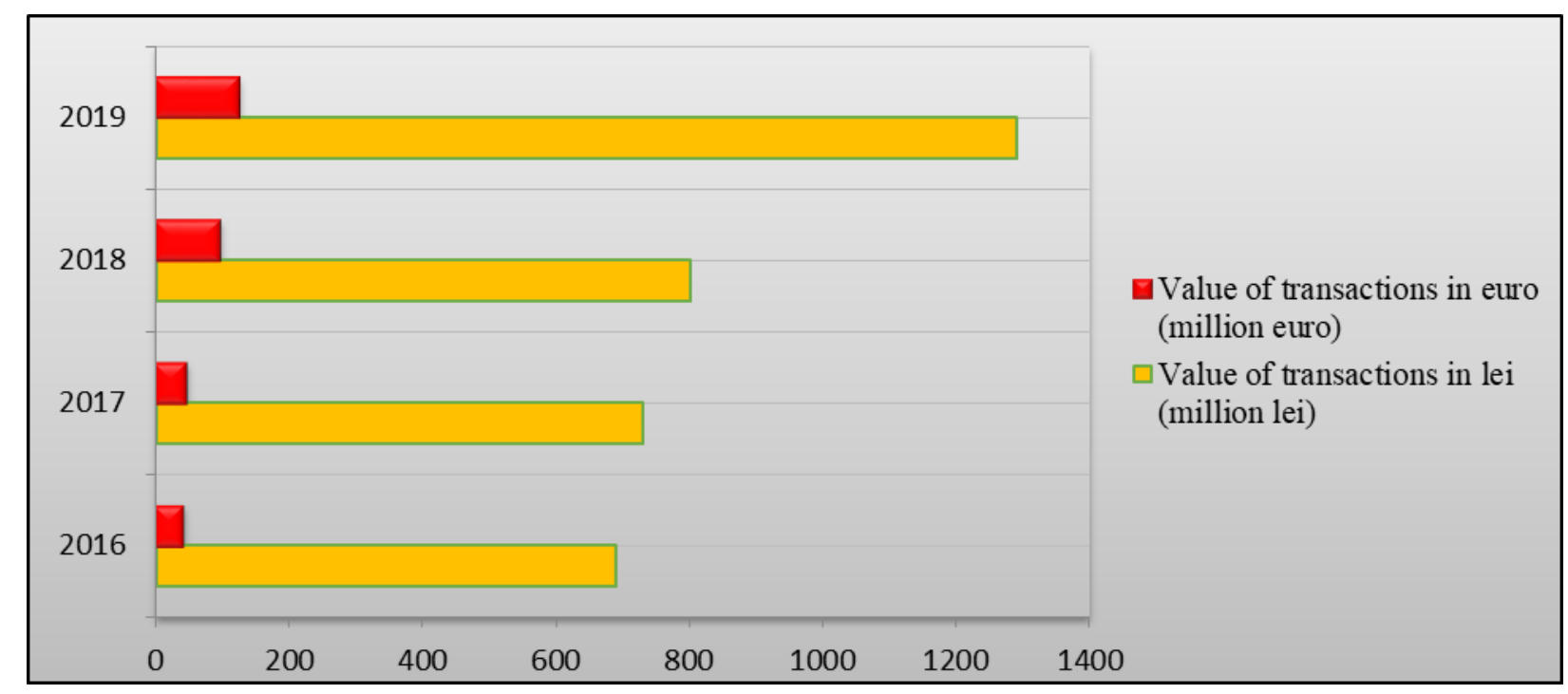

Figure 4. The value of transactions in lei and euro made by mobile banking in Romania Source: Elaborated by the authors, data from BNR reports

Regarding the value of the transactions, in the period 2016-2019, it is found that the highest value is the transactions in Lei, whose share in 2019 is $91.17 \%$. Both the value of transactions in Lei and in euro had an increasing evolution from year to year, as well as an overall evolution of the value of transactions. Thus, the value of transactions in Euro increased by 30.2\% in 2019 compared to 2018.

Using Mobile Banking to provide banking products and services has benefits for banks and customers, as shown in the table below:

Table 2. Mobile banking- benefits for banks and clients

\begin{tabular}{|c|c|}
\hline ENTITY & BENEFITS \\
\hline BANK & $\begin{array}{l}\text { Increasing the satisfaction of the client's requirements, due to the fact that this } \\
\text { service is available } 24 \text { hours a day, } 7 \text { days a week, leaving the client the choice when } \\
\text { and where to do their transactions; } \\
\text { Increasing the retention rate of the clients by eliminating the conditioning to the } \\
\text { physical location of a bank or the number of branches and the available personnel; } \\
\text { Possibility of regional expansion with very small investments in the physical locations } \\
\text { of branches or agencies; } \\
\text { Identifying customers or segments that are profitable for customers. A database with } \\
\text { complex customer information, which can be obtained through the website, can } \\
\text { facilitate the detailed analysis of each client or of certain groups of clients and } \\
\text { measure their profitability. Special profitable offers can be made to these profitable } \\
\text { customers; } \\
\text { Online banking transactions have the lowest costs of all types of transactions; } \\
\text { - Good image on the market. Banks that offer such services are perceived as leaders in } \\
\text { technology implementation, having a better image on the market. }\end{array}$ \\
\hline CLIENT & $\begin{array}{l}\text { - Reduced costs for accessing and using different banking products and services; } \\
\text { - Convenience. All banking transactions can be done from anywhere without going to } \\
\text { the bank's headquarters and at any time, independent of the bank's schedule; } \\
\text { - Speed. The response of the environment is very fast, so the client can wait until the } \\
\text { last minute to initiate a transfer of funds; } \\
\text { - Administration of funds. The client can have the history of the different accounts. } \\
\text { Integrated budgeting. Option that begins to be implemented in most banking } \\
\text { applications, through which we obtain statistics on monthly expenses and the } \\
\text { possibility of establishing monthly budgets for various expenses such as restaurants } \\
\text { or shopping, but also saving tools. }\end{array}$ \\
\hline
\end{tabular}

Source: Elaborated by the authors

Mobile banking, from the bank's point of view, reduces transaction management costs by reducing the need for customers to visit a bank branch for certain transactions.

Electronic banking is the range of banking services that can be made available by a bank to individuals and companies by electronic means, generally via a mobile phone or the Internet. These services allow the total or partial administration of a bank account, made by the account holder, the account being current or on term, without having to move the account holder to the bank branch. 


\section{Conclusions}

Providing customer services and meeting their needs is the key element for banks to increase profitability. Therefore, new technologies have enabled banks to provide services to customers not only in bank branches, but anywhere in the world, at any time. Mobile banking covers a whole range of banking services, such as money transfer, payment of bills, deposits etc.

Mobile banking is expanding in UE, due to the ease of opening an account and the security measures implemented. No security system is $100 \%$ secure, which is why it is important to respect the security measures, especially the protection of the pin and the access password, in order to remain safe.

in Romania, today, most of the banks offer an Internet banking service, including banking institutions having advantages through the use of this tool by customers: human intervention in the counters is avoided, the human resources allocated and the costs themselves are significantly lower.

The development of the business environment in Romania indirectly required a better offer from the banking environment. Competition in this market was not delayed: at present, banking institutions are trying to promote special new solutions, which they intend in time, to help modernize the way business in Romania works. The Internet Banking service, which allows full access to the company's current bank account, has many advantages, but is still underused at country level, perhaps due to the lack of adequate promotion.

In conclusion, the credibility and the perceived financial costs have a strong effect on the influence of the clients to adopt and use the service of Mobile Banking.

\section{References}

1. Ayswarya R., Sarala D., P. Muralidharan, M. Ilankadhir - Service Quality of Mobile Banking Services in ICICI Bank Limited", journal of Service Science and Management, vol.12, pag.649-664,2019, available at https://www.scirp.org/pdf/JSSM_2019081617002687.pdf

2. Cocriș Vasile, Chirlesan Dan - Tehnica Operațiunilor Bancare, Editura Universității, Al. I. Cuza, Iasi, 2006

3. Darlington, L. - Banking without Boundaries: How the Banking Industry Is Transforming Itself for the Digital Age, Blueprint for the Digital Economy, McGraw Hill, New York, 1999.

4. Goloşoiu-Georgescu Ligia - Mijloace, modalităţi şi instrumente de plată, Editura ASE, București, 2003.

5. Rosca Ion Gh., Bucur C. M., Timofte-Stanciu C., Paiu O., Visean M. - Comerțul electronic concepte, tehnologii și aplicații, Editura Economica, București, 2004.

6. Keivani, F.S.; Jouzbarkand, M.; Khodadadi, M.; Sourkouhi, Z.K. - A General View on the E-banking”, International Proceedings of Economics Development \& Research, 2012, available at http://ipedr.com/vol43/013-ICFME2012-M00033.pdf

7. Nedelescu M., Stănescu C.-Produse și servici bancare, Editura Universitară, București, 2012

8. Răbonțu C.I., Electronic Banking Services in Economy Based on Knowledge, Annals Economic Series Constantin Brâncusi University, Faculty of Economics, vol. 1, pages 49-68, 2009, available at

9. https://ideas.repec.org/a/cbu/jrnlec/y2009v1p49-68.html

10. Salehi, M.; Alipour, M. - E-banking in emerging economy: empirical evidence of Iran, International Journal of Economics and Finance, vol.2(1), pp.201-209, 2014

11. the websites of commercial banks operating in Romania

12. *** Ordinul nr. 553/2019 privind reglementarea procedurii de avizare a instrumentelor de plată electronică cu acces la distanță disponibil la

http://www.euroavocatura.ro/legislatie/1529/Ordinul_nr_553_2019_privind_reglementarea_procedurii_de_avizare_a_instrumentelor _de_plata_electronica_cu_acces_la_distanta

13. 12. ${ }^{* * *}$ Regulament BNR nr.6/2006 privind emiterea şi utilizarea instrumentelor de plată electronică şi relaţiile dintre participanţii la tranzacțiile $\mathrm{cu}$ aceste instrumente și precizările BNR referitoare la aplicabilitatea acestuia, disponibil la https://www.bnr.ro/apage.aspx?pid=404\&actId $=20$.

14. 13.www.mcsi.ro

15. 14.www.bnr.ro

16. 15.www.europa.eu 